\title{
Inventory and Regularity of Annals Publications of Lubumbashi Higher Institute for Statistics (Dr. Congo) from 1990 to 2015
}

\author{
Khang Ndipa Sabine, Abelelau Bokako Sosthene, Tshari Ngoie Hortance \\ Department of Marketing, Commercial and Financial Sciences Section, Lubumbashi Higher Institute of Statistics, Lubumbashi, \\ Democratic Republic of Congo \\ Email: michelnzaji@yahoo.fr
}

How to cite this paper: Sabine, K.N., Sosthene, A.B. and Hortance, T.N. (2017) Inventory and Regularity of Annals Publications of Lubumbashi Higher Institute for Statistics (Dr. Congo) from 1990 to 2015. Open Access Library Journal, 4: e3640. https://doi.org/10.4236/oalib.1103640

Received: April 30, 2017

Accepted: July 17, 2017

Published: July 20, 2017

Copyright $\odot 2017$ by authors and Open Access Library Inc.

This work is licensed under the Creative Commons Attribution International License (CC BY 4.0).

http://creativecommons.org/licenses/by/4.0/

\begin{abstract}
Within the scientific community, information essentially passes through scientific publications. These publications now occupy a prominent place in the search. They constitute the very purpose of scientific research as a researcher is usually assessed by its publications. The quality of scientific research combines punctuality and continuity over time. This reflection analyzes this question through the annals of the Higher Institute of Statistics of Lubumbashi. This study aims an inventory of scientific production and evaluates the legality of publications in the annals of this institution. We used the literature review. Through this review, we identified scientific publications in the various annals of the Stattistics Higher Institute of Lubumbash from 1990 to 2015. It appears from this study that an irregularity in the publication of the Annals was observed. 92 articles were published in the Annals of which 54 (58.7\%) by internal researchers in this institution and $38(41.3 \%)$ by external researchers. Three most productive sectors by internal authors namely the economic, statistical and computer were recorded. A resumption of publications occurred around the years 1998 and 1999 followed by a disappearance of a period of more than four years. The valorisation of the research activity in this university institution inevitably passes through the publication of the articles by the researchers of this institution and the regularity of the publication of their magazine.
\end{abstract}

\section{Subject Areas}

Statistics

\section{Keywords}

Inventory, Regularity, Annals Publications, Higher Institute for Statistics, Lubumbashi 


\section{Introduction}

Science is the result of scientists' research. This science progresses over time and with the work of scientists and researchers. Thus the second half of the twentieth century has been qualified as "Age of Science". Within the scientific community, information essentially passes through scientific publications. These publications now occupy a prominent place in the research. They constitute the very purpose of scientific research as a researcher is usually assessed by his publications [1].

Scientific communication and research are closely interrelated and even complementary. But it is not enough that the scientist communicates research results to other scientists in one form or another (for example oral communication in a seminar or conference). He must publish the results because "without publication, science is dead" [2].

Because written communication occupies a more and more important place in the scientific community, researchers must publish their results and research methods because the publishing operation is the very purpose of scientific research. Indeed, in the preface of his book, R. Day (1989) reports that scientists who begin their careers as students are evaluated neither by their skill laboratory manipulations (no one can know that unless their directors) nor their knowledge on a particular subject and certainly not by their charm. They are evaluated and become known through their publications [3].

The evaluation of Universities and Higher Institutes based on informetric criteria is now a reality. Institutional evaluation of researchers and scientific activity is based on the volume of scientific publications and the number of citations they receive. This indicator is important in a context of global competition, where the Universities and High Schools need a ranking of their researchers to have a better international positioning, based on their reputation in scientific databases.

Bibliometrics help the university authorities to measure the activity of the scientific production of their researchers, to define emerging research themes, and to position themselves both nationally and internationally [4]. Scientific production is an important indicator and factor of human development of a country. The objective of this study is to inventory the scientific production of the Higher Institute of Statistics and evaluate the regularity of the Annals of the latter.

\section{Methodology and Results}

We used the literature review. Through this review, we identified scientific publications in the various annals of the Stattistics Higher Institute of Lubumbash from 1990 to 2015. For articles published in a team in this study, only the man author was considered.

The first results that we have registered concern author names, article titles, numbers of articles published in the annals of the ISS from 1990 to 2015.

This Table 1 is rich in information. It first shows that the records did not appear every year. Note that there is a regularity in the early years and a disap- 
Table 1. Total number of articles published in the annals of the ISS/Lshi from 1990 to 2015.

\begin{tabular}{|c|c|c|}
\hline Year & Articles published & $\begin{array}{c}\text { Total } \\
\text { articles }\end{array}$ \\
\hline 1990 & October 1990 & 08 \\
\hline
\end{tabular}

\footnotetext{
1) The application of data analysis in determining homogeneous areas of maize crop in central and southern Shaba region.

By Munda Kalenge.

2) How to translate in full letters monetary value?

By Bope Bushebu.

3) Determination of the law binding the fines content at the limit of liquidity.

By Lunda Ilunga.

4) The freedom in independent Africa.

By Muya Bia Lushku Lumuna.

5) Test for formulating a formula to increase salary for public administration.

By Kakala Kisimba.

6) Creativity and cultural destiny: a formal anthropological perspective of the development of Zaire.

By Malemba Mukengeshayi N'sakila.

7) The impact of criteria for selecting candidates on their success in the first statistical graduate.

By Tshitenge Katanga.

8) Optimal allocation of human resources in various activities at each of the levels of scheduling a dynamic program tasks. By Kimamuka Ruriho.
}

9) Extension of Newton's formula "RATINGS" to calculate a definite integral and automatictest processing by a basic program. Leon Mishindo Mbucici.

10) The laser Helieum-Neon and its use in teaching physics laboratory PSI-Lubumbashi.

By Kabamba Mwenda Kazadi.

11) Empirical study of purchasing power parity (PPP) case of Belgicavs USA.

By Nguba Mundala.

12) Newspapers Procurement Policy.

By Bope Bushebu.

13) Signalético-symbolic study of the great spotted DUKE.

By Kazadi Ntambwe.

14) Factor structure of the selection criteria and results in first statistical year.

By Munda Kalenge.

15) Combinatorial analysis software.

By Mikobi Mingambengele.

16) The Africa's face the issue of development.

By Lunganga Kabundi.

17) Finding an optimal maintenance strategy of an article in a magazine with a rate imposed model. For VFYB $4 \times 4 \mathrm{cables}^{2} \mathrm{~cm}^{2}$ of lasimoirs seat and cabling Gécamines-Operating/Lubumbashi.

For Lenge Muzungu.

18) The pirate market: a curse or an emergency exit?

By Mwepu Myembwe.

19) The computer courses as a measure of student's intelligence.

By Bope Bushebu.

20) Data analysis methods for coding, by rows in the study assessing the efficacy of antimalarial drugs.

By Kimanuka Ruriho.

21) Test of optimal approach of the exploitation of public transport in the private sector in urban areas, in Zaire. Bus Case Mitsubishi and Coster on Ruashi-Lubumbashi line.

By Sumba Chenge.

22) Search for conditional moments at the rank $\mathrm{k}$ of realization of negative exponentiell random variable and approximation of its relative range.

23) Problem of index calculation made for consumption (case of application to simulated data in the city of Lubumbashi).

By Sumba Chenge.

24) Model of supply in a price instability situation in the market. 


\section{Continued}

By Ilunga Monga.

25) Key climate factors of actual evapotranspiration in region of high Fagnes (Belgium).

By Kalombo Kamutanda.

26) Determination of railway costs by category of trafic. Case of SFE.

By Kasongo Kasongo Wa.

27) Statistics and probability in quantum logic.

By Mutumba Mwembo.

28) Building the averages for math functions.

By Ilunga Monga.

29) Regression analysis: validity test of the general linear regression model.

By Ngoy Mwanabute.

30) The PME and development at Katanga.

By Kalam Kamb.

31) The continued depreciation of the Zaire currency and the erosion of purchasing power of the Zairian official. Case of the university teacher. Indices Analysis Test from December 1995 to March 1997.

By Dikasa Engondo.

32) The concept of management accounting in a railway company: Case SNCC.

By Kasongo Wa Kasongo.

33) Time series: a rereading of TFC written to the ISS.

By Kakala Kisimba.

34) The Tetela people, Chokwe and Bena-manda facing the undermining of traditional beliefs concerning control of adultery.

By Dikasa Engondo.

35) Creation, organization and evaluation of the African peasantry in Tanganyika district (1950-1960).

By Kalala Tshikanda.

36) Information System of spatial reference: a support system for the management of natural resources.

By Daniel Bavueza Munsana.

37) Use of artificial intelligence in the control of geometric parameters of a railway track.

By Kabeya Mwepu.

38) Hierarchical selection process of discriminating variables by the technique of step by step discriminating analysis in the case of several classes. Cases of man internal medicine to the hospital Send we Lubumbashi.

By Kasongo Ntambwe.

39) Promiscuity and the responsibility of parents towards education of their children in urban areas: the case of Congo neighborhood in the town of Ruashi.

By Dikasa Engondo.

40) Modeling references objects spatially.

By Daniel Bavueza Munsana.

41) The problem of wage determination in PMEs against the cost of living in Lubumbashi (January 2001 in May 2003).

By Nkulu Kateba Caleb.

42) New media storages of libraries information in the age of the internet.

By Ilunga Mbidi Kantolotolo.

43) Interpretation of a conflict: analysis test of the war in Somalia and possibility to redial.

By Kabika Etobo.

44) From the teaching of humanities in mathematics.

By Mululu Lulemire.

45) Socio-economic profile of the taxi-Moto in Beni Butembo and Gomatown.

By Kasereka Kaghesi.

46) Logistic Analysis of economic growth in a low economy conditions (case of the DRC).

By Nguba Mundala.

47) Risk assessment in the diagnosis of HIV/AIDS infections in Lubumbashi.

By Manya Tsheko. 


\section{Continued}

48) Logos action plan to the new partnership for African development. What a prospect for the revival of Africa.

By Kabika Etobo.

49) The Enlargement of the European Union and the issue of security after the Cold War.

By Kabika Etobo.

50) Strengthening the independence of the prosecutor during the pre-trial investigation. Case of preventive detention.

By Mwanza Mutombo.

51) The frequency of schistosomiasis in the urban area of health of MUYA.

By Tshiondo Shampa.

52) The prevalence of hemorrhoids in women at KITENGE clinic in Mbujimayi.

By Kabumba Kabumba.

53) The death penalty facing the resocialization of the convicted and human dignity in Congolese law.

By Balekelay Mulumba.

54) The role of statistics in the health institutions in the DRC.

By Mukalenge Tshikenda.

55) Divergence between the Congolese accounting system and international accounting standards. IAS/IFRS.

By Jhon Lwandu Muteba.

56) What public enterprise management mode of the DRC must be preconized after the elections?

By Marcel Ilunga Leu.

57) The poverty of the peasants land and social change (case of Kantama, Kalambay and Kalenda Kashile village of Oriental Kasai/DRC).

By Mukonkole Lemba.

58) Governance and industrialization in the DRC. What perspective of the post-Second Republic development?

By Badibanga Mpapa.

59) The Congolese contributions and the issue of qualification of political regimes: from CNS to DIC.

By Tshipinda Kasonga.

60) Study of temporal variation in the production of printed fabrics: modeling and forecasting. Case of the Sentex

kin/Lubumbashi 2001-2005.

By Mukalenge Tshikenda.

61) Acceptance Profile of intrauterine device in women in Mbuji-Mayi. Case of family planning service of BONJOLA hospital.

By Tshiondo Shampa.

62) Wage growth in the DRC myth or reality? (Case of academic and scientific staff of Mbuji-Mayi).

By Otshudi W'otshudi.

63) The Congolese constitution of the Belgian Congo in the DRC: ciphered kind, statistics and comments.

By Kapinga Ilunga.

64) International financial assistance: brake or accelerator for the development of backward countries.

By Kapinga Ilunga.

65) Planning deal with a country's development prospects. Case of DRC.

By Mbuyamba Cifuila.

66) Calculating model of clutter of a relational database.

By Bula Butupu.

67) The incidence of sexually transmitted diseases.

By Gilbert Ndomba Kamba-Kamba.

68) Application of the ABC approach to inventory management of small and medium business enterprise (case of Kabongo Ngoy institutions).

By Mpanga Matanga.

69) Construction of a translator of the basic language of instruction (case of visual basic Delphi).

By Kalombo Nshimba.

70) Problematic of private investment against the socio-economic development in Oriental Kasai.

By Tresor Jean Malizuku Okungu Osinga.

71) Market study of clothing products in Mbuji-Mayi.

For Tresor Jean Malizuku Okungu Osinga. 


\section{Continued}

72) Statistics: strategic tool for development of a nation.

By Nguba Mundala.

73) Interest of the residue theorem in a difficult integration.

By Mululu Lulemire.

74) Retaining the feasibility in artisanal heterogeneity in Africa.

By Daniel Mbiye Mukendi.

75) Measurement system of the complexity of an algorithm.

By Daili Kalombo Nshimba.

76) Designing a basic relational data from a computer system.

By Lucid Bula Butumpu.

77) Evaluation study of TIGO targets in DRC (April-November): Equity Research Test marketing mix.

By Medard Nguba Mundala.

78) Impact of artisanal mining and rational management of minerals in an urban environment: the case of the city of Likasi and its surroundings.

By Paul Kakubu Wa Vuvu.

79) The MWASHYA of Lwishaperipheral polygon: case of Kaleba deposit.

By Paul Kakubu Wa Vuvu.

80) The Problem of choosing a data model in solving a management problem.

Elie Louis Kabwe Kionde.

81) Application of queuing models in determining the characteristics of hospital capacity (case of the UNHCR/Katuba in 2004).

By Louis Sumba Chenge.

82) Back of Julien KILANGA MUSINDE crank: a duty to remember?

By Jean Kashombo M’tompa.

83) Differences of evaluation and presentation of balance sheet accounts of the OHADA accounting system by international accounting standards.

By John Luandu Tshilenyo Muteba.

84) Frequency of parasitic infections fecally spreaded isolated in the health center ORT—Congo Katuba social care home in Lubumbashi.

By Manya Tsheko, Katumba Mashimabi.

85) Financial diagnosis sketch of the Utex Africa through the multi-annual table of financial flows (2003-2005).

By Clement Masiala Sueka Pola.

86) Construction of a statistical function of classroom language (more more).

By Peter Mutshapa Tujenge.

87) Resolution of generalized integral by the second form of the BELA function.

By Malamba Lubelo.

88) The problem of database in drafting a working end accounting cycle.

By Gerard Kakala Kisimba.

89) Diagnostic test of traffic to the post place of Lubumbashi.

Elie Etshiloni Kabaso.

90) The design and implementation of a scientific research project. Lived experience.

By Louis Sumba Chenge.

91) Microcredit, the Lubumbashi women work and the fight against poverty.

By DikasaEngondo.

92) Access to medicines in a mutual system study on mutual health care of agents of Lubumbashi University.

By Umba Kasongo.

Sources: Annals of the Higher Institute of Statistics of Lubumbashi 
pearance of the records of more than seven years. A resumption of publications occurred around the years 1998 and 1999 followed by a disappearance of a period of more than four years.

Another finding that emerges from this Table 2 concern the number of articles per year from 4 to 24 with an average publication of approximately 7 items per year. The years 2004 and 2015 were, as indicated in this Table II, the least productive with 4 items. But it should be noted that there was an irregularity in the publication of the review of this institution from 1991 to 1998 but also from 2010 to 2015.

It appears from this Table 3 that 26 internal researchers published their works in the annals of the Higher Institute of Statistics since its inception. In addition, Table III showed that the majority has produced only one article. But there are authors who have made exception as Sumba Chenge, Nguba Mundala and Dikasa Engondo with four articles each followed by Bope Bushebu who has three items. Economic, statistical and computing domains were the most requested.

This Table 4 showed that the Annals of the statistic Higher Institute of Lubumbashi has an echo outside. Note that 35 external researchers were able to publish 46 items. Regarding productivity Kabika Etobo achieved the most high number of articles, (three). Six other Tshiondo Shampa Manya Tsheko, Malizuku Okungu, Lwandu MutebaJhon, Kapinga Ilunga and Bavweza Munsana have published two per each. While others appear each with a single publication.

\section{Discussion}

This study was performed on the database of Lubumbashi ISS annals which includes a body of 92 scientific articles by 61 research professors. Analysis of these data has produced the first scientific production evaluation indicators of this university.

Table 2. Number of articles published per year from 1990 to 2015.

\begin{tabular}{ccc}
\hline Year & Number of issues & Number of Items \\
\hline 1990 & 1 & 8 \\
1991 & 1 & 12 \\
1998 & 1 & 8 \\
1999 & 1 & 5 \\
2003 & 1 & 5 \\
2004 & 1 & 4 \\
2007 & 3 & 24 \\
2008 & 1 & 7 \\
2009 & 1 & 7 \\
2010 & 1 & 8 \\
2015 & 1 & 4 \\
& & 92 \\
\hline
\end{tabular}

Sources: Annals of the Higher Institute of Statistics of Lubumbashi. 
Table 3. Internal authors, fields, numbers and years of publication.

\begin{tabular}{|c|c|c|c|c|}
\hline $\mathbf{N}^{\bullet}$ & Names and post names & Estate of publication & $\begin{array}{c}\text { Publication } \\
\text { Number. }\end{array}$ & $\begin{array}{c}\text { Year of } \\
\text { publication }\end{array}$ \\
\hline 1 & Bope Bushebu & Statistical & 3 & 1990,1991 \\
\hline 2 & Bula Butumpu & Data processing & 2 & 2007,2009 \\
\hline 3 & Dikasa Engondo & Sociology & 4 & $1999,2003,2004,2015$ \\
\hline 4 & Etshiloni Kabaso & Statistical & 1 & 2015 \\
\hline 5 & Kabeya Mwepu & Economic & 1 & 2003 \\
\hline 6 & Kabwe Kionde & Data processing & 1 & 2009 \\
\hline 7 & Kakala Kisimba & Statistics, Economic & 3 & 1990, 1999, 2010 \\
\hline 8 & Kalala Tshikanda & History & 1 & 2003 \\
\hline 9 & Kalam Kamb & Development & 1 & 1999 \\
\hline 10 & Kalombo Nshimba & data processing & 2 & 2008,2009 \\
\hline 11 & Kasongo Ntambwe & Statistical & 1 & 2003 \\
\hline 12 & Lunganga Kabundi & Sociology & 1 & 1991 \\
\hline 13 & Malamba Lubelo & Statistical & 1 & 2010 \\
\hline 14 & Masiala Sueka Pola & Economic & 1 & 2010 \\
\hline 15 & Mikobi Minga Mbengele & Statistical & 1 & 1991 \\
\hline 16 & Mishindo Mbucici Leon & Statistical & 2 & 1991, 1998 \\
\hline 17 & Ilunga Monga & Statistical & 2 & 1998 \\
\hline 18 & Mpanga Matanga & Economic & 1 & 2008 \\
\hline 19 & Mukalenge Tshikenda & Statistical & 2 & 2007 \\
\hline 20 & Mululu Lulemire & Didactics & 2 & 2007,2008 \\
\hline 21 & Munda Kalenge & Agronomic & 2 & 1990,1991 \\
\hline 22 & Mutchapa Tujenge & data processing & 1 & 2010 \\
\hline 23 & Ndomba Kamba-Kamba & Statistical & 1 & 2008 \\
\hline 24 & Nguba Mundala & Economic & 4 & $1991,2007,2008,2009$ \\
\hline 25 & Caleb Nkulu Kateba & Statistical & 1 & 2004 \\
\hline \multirow[t]{2}{*}{26} & Sumba Chenge & Economic & 4 & 1998, 2010, 2015 \\
\hline & Total 26 & & 46 & \\
\hline
\end{tabular}

Sources: Annals of the Higher Institute of Statistics of Lubumbashi.

1) This table thus brings some irregularity in publishing annales. This paradoxical situation may have several explanation factors namely: product failures accused by the leaders of the research center and the journal. These are the positions that are not paid, therefore do not show advantage; these not motivated responsible prefer to dedicate their time and energies to extra-professional activities which bring some things to the menager budget. Indeed precariousness and condition of life brings the population to multiply, diversify the activities that generate income for the household [5]. 
Table 4. External authors, fields, numbers and years of publication.

\begin{tabular}{|c|c|c|c|c|}
\hline $\mathrm{N}^{\circ}$ & Names and post names & Estate publication & Publicat number & Year of publication \\
\hline 1 & Badibanga Mpapa & Sociological & 1 & 2007 \\
\hline 2 & Balekelay Mulunda & Legal & 1 & 2007 \\
\hline 3 & Bavweza Munsana & data processing & 2 & 2003,2004 \\
\hline 4 & Ilunga Mbidi & data processing & 1 & 2004 \\
\hline 5 & Marcel Ilunga Leu & Economic & 1 & 2007 \\
\hline 6 & Kabamba Mwenda Kazadi & data processing & 1 & 1991 \\
\hline 7 & Kabika Etobo & sociological & 3 & 2007 \\
\hline 8 & Kabumba-Kabumba & Medical & 1 & 2007 \\
\hline 9 & Kalombo Kamutanda & Demographic & 1 & 1998 \\
\hline 10 & Kapinga Ilunga & Legal & 2 & 2007 \\
\hline 11 & Kasereka Kaghesi & Economic & 1 & 2007 \\
\hline 12 & Kashombo Ntompa & $\begin{array}{c}\text { French language and } \\
\text { literature }\end{array}$ & 1 & 2010 \\
\hline 13 & Kasongo Kasongo wa & Accounting & 2 & 1998,1999 \\
\hline 14 & Kazadi Ntambwe & sociological & 1 & 1991 \\
\hline 15 & Kimanuka Ruriho & Statistical & 2 & 1990,1991 \\
\hline 16 & Katanga Tshitenge & Statistical & 1 & 1990 \\
\hline 17 & Lenge Muzungu & Economic & 1 & 1991 \\
\hline 18 & Lunda Ilunga & Chemistry & 1 & 1990 \\
\hline 19 & Lwandu Muteba Jhon & Accounting & 2 & 2007,2010 \\
\hline 20 & Malemba Mukengeshayi & Anthropology & 1 & 1990 \\
\hline 21 & Malizuku Okungu O. & Economic & 2 & 2008 \\
\hline 22 & Manya Tsheko & Medical & 2 & 2007,2010 \\
\hline 23 & Mbiye Mukendi & Economic & 1 & 2009 \\
\hline 24 & Mbuyamba Cifuila & Demography & 1 & 2007 \\
\hline 25 & Mukonkole Lemba Lemba & Statistical & 1 & 2007 \\
\hline 26 & Mutunda Mwembo & Statistical & 1 & 1998 \\
\hline 27 & Muya Bia Lushiku & History & 1 & 1990 \\
\hline 28 & Mwanza Mutombo & Legal & 1 & 2007 \\
\hline 29 & Mwepu Nyembwe & Development & 1 & 1991 \\
\hline 30 & Ngoy Mwanabute & Statistical & 1 & 1999 \\
\hline 31 & Otshudi W'otshudi & Economic & 1 & 2007 \\
\hline 32 & Paul Kakubu & Economic & 2 & 2009 \\
\hline 33 & Tshiondo Shampa & Medical & 2 & 2007 \\
\hline 34 & Tshipinda Kasonga & Legal & 1 & 2007 \\
\hline \multirow[t]{2}{*}{35} & Umba Kasongo & Medical & 1 & 2015 \\
\hline & Total 35 & & 46 & \\
\hline
\end{tabular}

Sources: Annals of the Higher Institute of Statistics of Lubumbashi. 
2) The higher institute of statistics are not well supplied with provided and specialised library, this characterizes the institutions of higher education and university in the Democratic Republic of Congo [6], the lack of a provided library constitutes a disincentive factor.

3) The living conditions of precariousness condemning the researcher to publish only when they are in need of a promotion. The few means available is spent on household survival where they are leaders. This feature is the basis of disappearance of research culture. People are moved by the spirit of survival. We must try to ensure the survival of the household rather than devote to research. This latter (reseach) becomes an unnecessary luxury. It should be noted that the state bears a heavy responsibility regarding radiation of the research. It is since the year 1980 that the public can no longer disponibilise required means to allow the upper educational institutions and university to make research.

4) These establishments operate only thanks to the fees paid by students. Research has not the place in the use of this money more; there is no policy of the state to encourage partnerships with private companies. It is the combination of these factors which carries a mortal blow to the research in high educational institutions and university, not just in the upper statistical institute but in all the democratic republic of Congo.

In addition to these factors listed, let us add other factors like: lack of supervision. Junior researchers (assistant and head of research) are deprived of appropriate supervision of seignor researcher (professors) who pass the bulk of their bread in remunerative Activities.

In short lethargy observed in the publication of annals has its main cause from the deterioration of living conditions, working condition. The irregularity in the publication of the annals of this period of study is obvious. This aspect can be explained firstly by the fact that probably the vast majority of researchers of this institution have not deposited their research works in these records, but they are ready to do so if they are accompanied by their institution. Second, we believe that some researchers of higher institute of statistics published in other journals for the following reasons: faster process, acceptance criteria of items less rigid, making the institution's journal suffers from lack of submission. However the researchers of this institution should be aware that the valuation of the research activity inevitably involves scientific journals and we know how important it is for researchers to publish in the most respected journals in their discipline, which does not exist in the city of Lubumbashi.

According to the study conducted by Hanae, the number of publications had increased significantly in their study and this increase was related to a strong relationship with the recruitment of a significant number of assistants in the emergency program "2009-2013" for the reform of higher education [7]. But the regularity in the publication of Kamina University annals resulted in the tremendous work that the scientific committee of the journal lamp to increase the image of their institution. It was it which, together with the quality of the 
records, partly justify the interest of outside researchers vis-à-vis the journal of the University of Kamina [8].

The results of internal publications authors have placed on top three most productive sectors namely economic, statistical and computing. This can be explained by the different options organized by this institution. Note that the magazine, is the one that especially vehicle research results, it is indeed not only a mediator object, but also the instance of setting visibility pipes investigations, and therefore their evaluation, and the evaluation of their authors. Thus it is also invested mediation instance of a political and social role to affirm both the positioning of researchers and discipline in a context where it is always difficult to place.

While most researchers have stopped looking after one or two publications is that the main reason behind their production was not looking for a new knowledge or practice, the benefit of the community, to those already existing, but rather looking for a promotion as the transition from the grade of assistant to that of head of research. Once installed in his new chair, former researcher would block the source of its productions. To better explain the value of an article and its place in the career of a researcher Devillard cites in his thesis that "academia is linked closely to the traditional academic reward system ... which means that in terms of career advancement a published article has much more value than an experienced business executive [9].

So to advance its research and be known by the scientific community, a researcher must publish and inform others of what he is doing and what he works. He must publish at all stages of research and not wait until they come to the end. According to Devillard \& Marco (for career, each basic researcher is obliged to publish the results of his work) [10].

So to fight against this scientific lethargy found on the part of our researchers, some strategies can be recommended. Besides on this, the ministerial guardianship had given specific directions inviting the scientist researcher not to work on his own, but to closely link his services to the company's foundation in which he unfolds [11] [12].

\section{Conclusions}

The visibility setting is essential to enable scientific advances since research builds on the work that preceded it. Thus awareness can be estimated by the number of publications or the number of citations. But below and beyond the citation, it is good to expose the real scientific advances.

With 26 domestic authors who have produced 46 articles and 35 external that have published 46 articles, a total of 92 items produced by 61 authors from 1990 to 2015 , it is enough to recognize the work done by this crucible knowledge. Scientific journals are an essential component of the functioning of the research. The valorisation of the research activity in this university institution inevitably passes through the publication of the articles by the researchers of this institution and the regularity of the publication of their magazine. 
That's why we suggest at this institution management committee to strive for consistency in the publication of the Annals but also to push the scientists of the Alma Mater to research that is the second of three missions that the Congolese state has entrusted to his universities and higher institutes and resulting in the existence of a post of chief of section in charge of research in each section.

\section{References}

[1] Romdhane, M.B. (1996) Analysis of Scientific Publications: Characteristics, Structures and Languages.

http://www.enssib.fr/bibliotheque-numerique/documents/1652-analyse-des-publica tions-scientifiques-caracteristiques-structures-et-langages.pdf

[2] Timbal-Duclaux, L. (1990) Scientific and Technical Written Communication: Quality and Readability: Knowledge of the Problem, Practical Applications. Continuing Education in the Humanities, Modern Publishing Company ESF-1990, Paris, 11.

[3] American Proverb (1989) Without Publication, Science Is Dead. DAY, 8.

[4] Lefebvre, M. (2008) Evaluation of Scientific Knowledge: Methods and Issues. Scientific Publishing: Analysis and Prospects, Hermes, 299-316. http://archivesic.ccsd.cnrs.fr/docs/00/42/99/67/PDF/Lefebvre_chap_evaluation.pdf

[5] Lrhoul, H., Ghislaine, C., Bachr, A. and ByadiBouchra, O.B. (2014) Open Access: For Better Visibility of the Medical Scientific Production in Morocco, 2014. In CILA 2014: Open Access And Scientific Research: Towards New Values, Manouba, 27-28 November 2014. [Conference Paper]

[6] Petit, P. (2000) Households Lubumbashi between Precariousness and Redial. The Hamarttan, Paris, 118.

[7] DibweDiaMwembu (2002) The Social Role of the University of Lubumbashi, Lubumbashi University Press, Lubumbashi.

[8] Mande, I.J., Lenge, M.B. and Muleka, K.C. (2016) Inventory and Regular Publications of the Annals of the University of Kamina, from 2004 to 2014. In the Annals of the University of Kamina, Vol XV, July 2016.

[9] Devillard (1969) The Experienced Manager: A Major Resource. Reported by Mant, A., British Institute of Anagement, London, 25.

[10] Joëlle, D. and Luc, M. (1993) Write and Publish in a Scientific Journal. Editions d'Organization, Paris, 13.

[11] MalembaN’Sakila, G. (2011) Social Sciences in DRC, CRESA, Lubumbashi, 132-137.

[12] Mgr. Luc Gillon quotes Guy Malengreau; (2008) The University Lovanium, Distant Origins to 1960. African University, Kinshasa, 16. 
Submit or recommend next manuscript to OALib Journal and we will provide best service for you:

- Publication frequency: Monthly

- 9 subject areas of science, technology and medicine

- Fair and rigorous peer-review system

- Fast publication process

- Article promotion in various social networking sites (LinkedIn, Facebook, Twitter, etc.)

- Maximum dissemination of your research work

Submit Your Paper Online: Click Here to Submit

Or Contact service@oalib.com 